О. А. Подплєтня, Т. М. Потапова, В. Ю. Слєсарчук

ДЗ “Дніпропетровська медична академія МОЗ України”, м. Дніпро

\title{
ІННОВАЦІЙНІ ТЕХНОЛОГІЇ В ПРОФЕСІЙНІЙ ОСВІТІ: СУЧАСНІ ТЕНДЕНЦІЇ ТА ПРАКТИКА ВПРОВАДЖЕННЯ
}

\author{
O. A. Podpletnya, T. M. Potapova, V. Yu. Slesarchuk \\ Dnipropetrovsk Medical Academy, Dnipro

\section{INNOVATIVE TECHNOLOGIES IN PROFESSIONAL EDUCATION: CURRENT TRENDS AND IMPLEMENTATION PRACTICES}

\begin{abstract}
Мета роботи - висвітлити досвід застосування дистанційної форми навчання, яка працює на відкритій і найбільш популярній у світі платформі - Moodle, для підвищення якості підготовки висококваліфікованих фахівців-провізорів у Дніпропетровській медичній академії.

Основна частина. У статті розглянуто досвід впровадження новітніх інноваційних технологій навчання, які використовуються викладачами на кафедрі загальної та клінічної фармації при підготовці фахівця-провізора. Показано особливості дистанційної системи навчання, iї переваги. Оцінка ефективності використаних інноваційних технологій проводиться протягом усього терміну навчання конкретної дисципліни, шляхом тестування та постійного контролю і перевірки опанування теоретичного матеріалу та практичних навичок перед початком кожного практичного чи лабораторного заняття. Показана ефективність використання дистанційної системи навчання як позааудиторної форми організації самостійної роботи студентів.

Висновки. Інноваційні технології навчання сприяють розвитку пізнавальних і когнітивних здібностей студентів, а саме вміння вирішувати поставлені завдання, займатися збором, аналізом і синтезом даних, витягувати з них інформацію, самостійно мислити, володіти комунікативними навичками. Освітні технології відкривають нові горизонти викладання, навчання й оцінки здобутих знань, дозволяють втілювати інноваційні, ефективні моделі адміністрування та управління. Здійснювати постійний моніторинг оволодіння професійними компетенціями, що дозволяє за короткий строк відкоректувати та індивідуалізувати процес навчання. Дистанційні системи навчання надають можливості безперервного навчання, забезпечуючи великому колу людей можливість отримання як післявузівської, так і додаткової освіти.
\end{abstract}

Ключові слова: освіта; інноваційні технології; MOODLE; дистанційне навчання.

The aim of the work - to highlight the experience of applying distance learning, which works in the open and most popular worldwide platform - Moodle, to improve the quality of training of highly skilled pharmacists in the Dnipropetrovsk Medical Academy of the Ministry of Health of Ukraine.

The main body. The article examines the introduction of the latest innovative teaching technologies used by teachers at the department of general and clinical pharmacy in the preparation of a specialist-observer. The features of distance learning system, its advantages are shown. The assessment of the effectiveness of the used innovative technologies is conducted throughout the entire period of study of a particular discipline, by testing and continuous monitoring and verification of the mastery of theoretical material and practical skills before the beginning of each practical or laboratory lesson. The efficiency of the use of distance learning system as a non-auditory form of organization of independent work of students is shown.

Conclusions. In this way - innovative learning technologies contribute to the development of cognitive and cognitive abilities of students, namely - the ability to solve problems, collect, analyze and synthesize data, extract information from them, think independently, and have communicative skills. Educational technologies open new horizons of teaching, learning and evaluation of the acquired knowledge, allow to implement innovative, effective models of administration and management. To continuously monitor the acquisition of professional competencies, which allows for adjusting and individualizing the learning process in a short time. Distance learning systems provide opportunities for continuous education, providing a large range of people with the opportunity to receive postgraduate and additional education.

Key words: education; innovative technologies; MOODLE; distance learning.

Вступ. Основою стратегії сучасної освітньої політики є сполучення поточно-групової організації із побудовою особистісно-орієнтованого освітнього середовища з залученням та використанням засобів інформаційно-комунікаційних технологій. Одним

(ㄱ О. А. Подплєтня, Т. М. Потапова, В. Ю. Слєсарчук iз таких засобів є система дистанційного навчання (СДН). Дистанційне навчання, за визначенням А. А. Андрєєва, - це синтетична, інтегральна, гуманістична форма навчання, що грунтується на використанні широкого спектра традиційних та нових інформаційних технологій і їх технічних 
засобів, що використовуються для доставки навчального матеріалу, його самостійного вивчення, організації діалогового обміну між викладачем та студентом, коли процес навчання не залежить від їхнього розташування в просторі і в часі, а також до конкретної освітньої установи [1].

СДН - це форма здобуття освіти, при якій в освітньому процесі використовуються кращі традиційні та інноваційні засоби, а також форми навчання, що грунтуються на комп’ютерних і телекомунікаційних технологіях [2].

Для розвитку дистанційного навчання необхідні певні платформи, без яких СДН неможлива. Платформа - це програмне забезпечення для підтримки дистанційного навчання. На сьогодні існує значна кількість платформ для організації дистанційного навчання, які поділяються на дві великі категорії: 3 закритим кодом (комерційні); відкритим кодом (поширюються безкоштовно) [3].

Moodle - це система управління вмістом сайта, спеціально розроблена для створення якісних онлайн-курсів викладачами. За статистикою, що розміщена на сайті Moodle, станом на січень 2014 р. у світі зареєстровано 65 млн користувачів, 6 млн курсів та 64 тис. сайтів в 233 країнах світу [Moodle [Електронний ресурс]. - https://moodle. org/]. Інтерфейс системи дистанційного навчання Moodle переведений на 82 мови. На сьогодні система дистанційного навчання Moodle $€$ найпоширенішою системою дистанційного навчання 3 найбільшою кількістю користувачів і розробників.

Мета роботи - висвітлити досвід застосування дистанційної форми навчання, яка працює на відкритій і найбільш популярній у світі платформі Moodle, для підвищення якості підготовки висококваліфікованих фахівців-провізорів.

Основна частина. Платформа дистанційного навчання Moodle відповідає особливій філософії навчання, яку коротко називають “педагогікою соціального конструкціонізму” (social constructionist pedagogy). Суть її полягає в тому, що викладач перестає бути просто “джерелом знань” і перетворюється на режисера навчального процесу, орієнтуючись на індивідуальні потреби особистості, одночасно 3 цим направляючи дискусії і діяльність студентів на досягнення загальних навчальних цілей [4].

Перевагами Moodle над іншими системами є можливість розширення за рахунок зовнішніх модулів, достатньо розвинута система звітності, підтримка зовнішніх тестів, а також високий ступінь надійності та відсутність обмежень за кількістю слухачів. Недоліками системи є високі вимоги до кваліфікації спеціалістів для налаштування та підтримки системи; необхідність використання потужного сервера та широкого каналу [5].

Для підтримки дистанційної форми навчання в Дніпропетровській медичній академії у 2014 р. було створено спеціальний сервер дистанційного навчання, що працює на відкритій і найбільш популярній у світі платформі - Moodle, що розміщена в мережі “Інтернет” за адресою: http://moodle. dma.dp.ua/ [6].

Головна мета впровадження Moodle - надати ініціативним викладачам і студентам вільний доступ до системи, яка дає змогу ефективно обмінюватися навчальним контентом, взаємодіяти он-лайн та використовувати сучасні технології для втілення в життя принципу “навчання будь-коли та будь-де”.

Викладачами кафедри загальної та клінічної фармації створено такі курси: “Загальна фармакологія”, “Органічна хімія”, “Аналітична хімія”, “Фізколоїдна хімія”, “Фармацевтична хімія”, “Медична хімія”, “Клінічна фармакологія”, “Аптечна технологія ліків”, “Заводська технологія ліків” для студентів 1-5 курсів за фахом “Фармація”, “Клінічна фармація”, а також для студентів заочної форми навчання. Зокрема, для студентів заочної форми навчання така система надає можливість готуватися до екзаменаційних сесій протягом року в зручний для них час, не відриваючись від роботи.

Кожен електронний навчальний курс містить файли з інформацією: назва теми; вид заняття (лабораторно-практичне, практичне); ціль заняття; зміст програми; основна та додаткова література; глосарій; вправи для закріплення; контрольні питання; тестові завдання (рис. 1).

У файлах викладачі розміщують навчально-методичні матеріали, які студенти активно використовують для підготовки до занять та самоперевірки своїх знань, перелік питань до наступного практичного чи лабораторного заняття та обов'язкове домашнє завдання, без виконання якого студент не має можливості повноцінно працювати на занятті (рис. 1).

Виконане домашнє завдання викладач може перевірити як на сайті, так і в роздрукованому вигляді перед початком заняття в кожного студента.

Також викладачі розміщують відеофайли для більш наглядного та детального поглиблення в поточну тематику заняття. I як заключний етап підключена база тестів для самопідготовки до ліцензійного іспиту “Крок 1” та “Крок 2" відповідно до поточної теми. Також створено окремий курс 


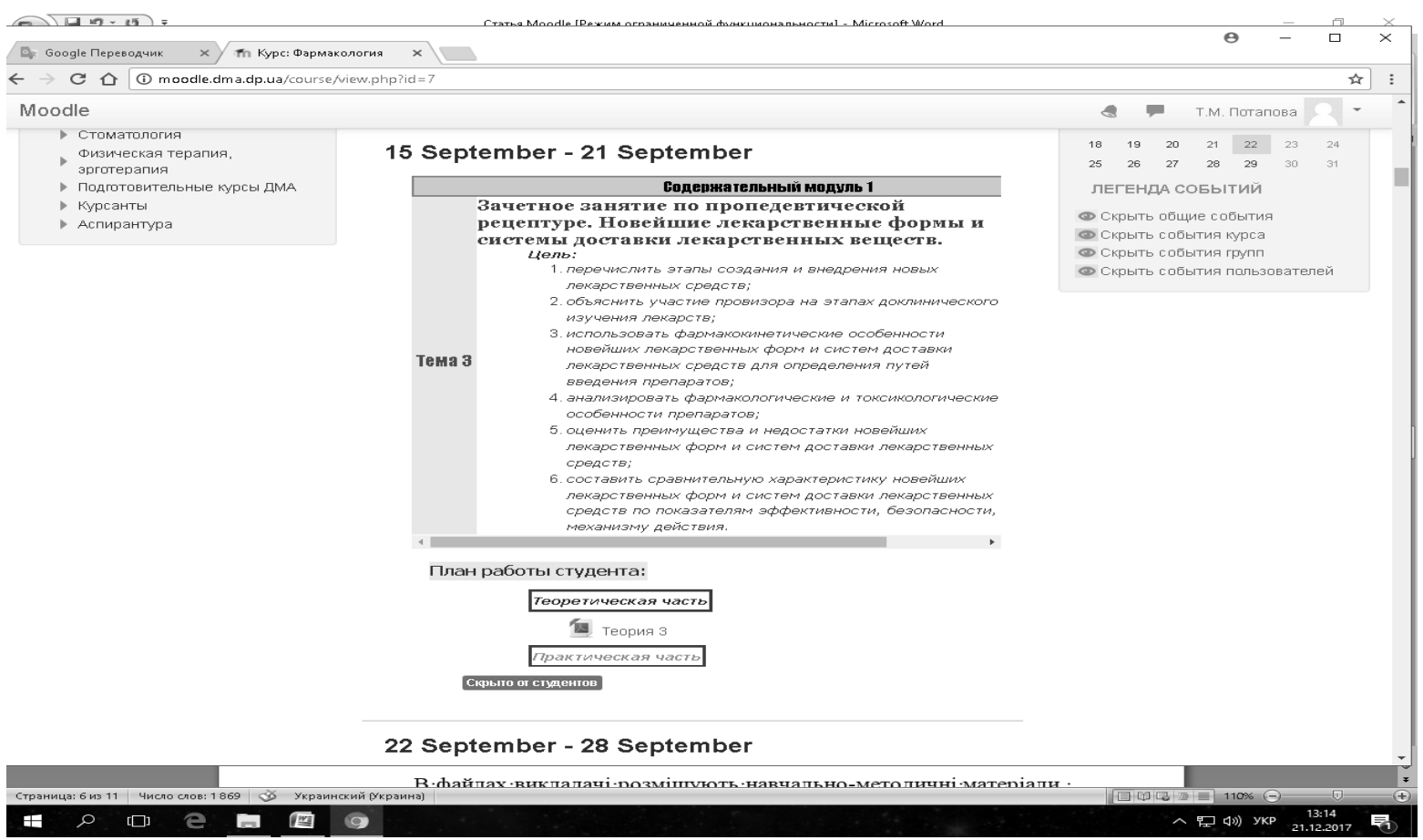

Рис. 1. Приклад сторінки електронного навчального курсу з фармакології.

“Підготовка до ліцензійного екзамену” “Крок 1” та “Крок 2”, де студент може знайти всі тести, розподілені по дисциплінах та за тематикою.

Після проходження тесту викладач може переглянути звіт про виконання тесту, в якому вказано дату та час входження в систему, скільки часу знадобилося кожному студенту на його проходження, й оцінку, яку він отримав у відсотковому вираженні. При цьому викладач може оцінювати як всю тему, так і окремий тест, над яким працював студент (рис. 2).

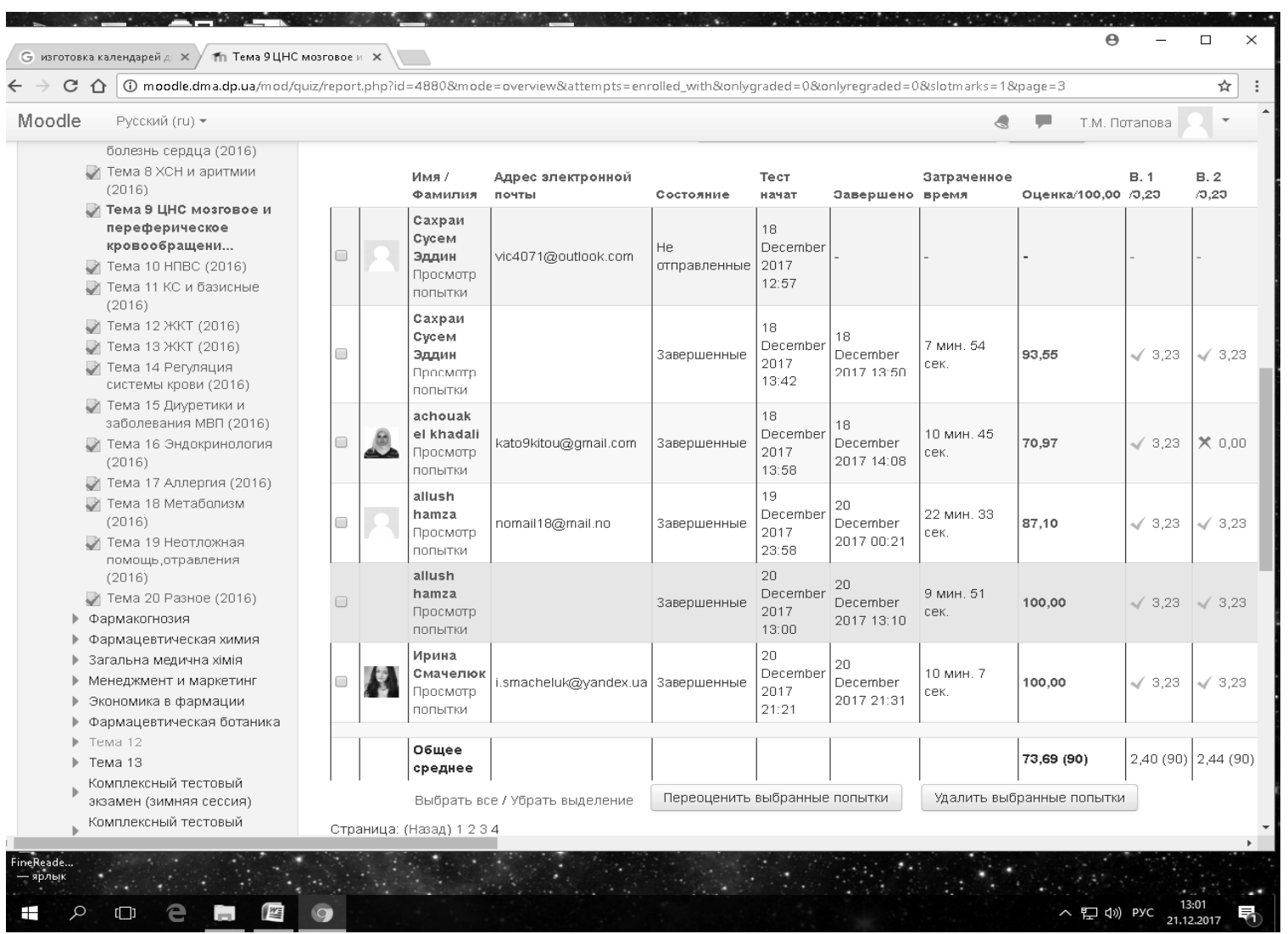

Рис. 2. Приклад електронної сторінки зі звітом про складання тестових завдань. 
Висновки. Таким чином, новітні інноваційні освітні технології дають широкі можливості диференціації та індивідуалізації навчальної діяльності. Результат застосування освітніх технологій залежить не стільки від майстерності викладача, скільки від мотивації та можливості студента до самонавчання, аналізу використаної літератури.

Освітні технології пов'язані з підвищенням ефективності навчання і виховання і спрямовані на кін-

\section{Список літератури}

1. Кухаренко В. М. Дистанційне навчання та умови застосування / В. М. Кухаренко, О. В. Рибалко, Н. Г. Сиротенко. - Х., 2002. - 320 с.

2. Трайнев В. А. Дистанционное обучение и его развитие / В. А. Трайнев, В. Ф. Гуркин, О. В. Трайнев. -2-е изд. - М. : Издательско-торговая корпорация “Дашков и К”, 2008. - 294 с.

3. Сисоєва С. О. Системи дистанційного навчання: порівняльний аналіз навчальних можливостей [Електронний ресурс] / С. О. Сисоєва, К. П. Осадча. - 2011. Режим доступу : http://www.academia.edu/931578.

4. Богомолов А. В. Обзор бесплатных систем управления обучением / А. В. Богомолов // Educational Technology \& Society. - 2007. - 10 (3).

\section{References}

1. Kukharenko, V.M., Rybalko, O.V., \& Sirotenko, N.H. (2002). Dystantsiine navchannia ta umovy zastosuvannia [Distance learning and terms of use]. Kharkiv [in Ukrainian].

2. Traynev, V.A., Gurkin, V.F., \& Traynev, O.V. (2008). Distantsionnoe obuchenie i ego razvitie [Distance learning and its development]. Moscow: Izdatelsko-torgovaya korporatsiya "Dashkov i K" [in Russian].

3. Sisoyeva, S.O., \& Osadcha, K.P. (2011). Systemy dystantsiinoho navchannia: porivnialnyi analiz navchalnyh mozhlyvostey [Distance learning systems: A comparative study of learning opportunities]. Retrieved from: http:// www.academia.edu/931578 [in Ukrainian].

4. Bogomolov, A.V. (2007). Obzor besplatnykh sistem upravleniya obucheniem [An overview of free learning management systems]. Educational Technology \& Society, 10 (3). Retrieved from: http://ifets.ieee.org/russian/depository/vlo_i3/html/9_bogomolov.htm [in Russian]. цевий результат освітнього процесу - це підготовка висококваліфікованих фахівців, здатних успішно освоювати нові, професійні та управлінські області, гнучко і динамічно реагувати на мінливі соціально-економічні умови; володіють високими моральними і громадянськими якостями в умовах інноваційного освітнього простору.

5. Гладир А. I. Системи дистанційного навчання огляд програмних платформ / А. І. Гладир, Н. В. Зачепа, О. О. Мотруніч // Проблеми вищої школи. Інновації в освіті та виробництві. Комп’ютерні технології в освіті та виробництві. - C. 43-44. - URL : http://www.kdu.edu. ua/statti/Tezi/Tezi_2012/43.pdf.

6. Перспективи впровадження сучасних інформаційних технологій в учбовий процес вищих медичних навчальних закладів / І. В. Машейко, Г. Б. Пелешенко, I. Ю. Письменецька, А. М. Машейко // Формування сучасної концепції викладання природничих дисциплін у медичних освітніх закладах : матеріали VIII наук.-практ. конф. - Х., 2015. - С. 14.

5. Gladir, A.I., Zachepa, N.V., \& Motrunich, O.O. (2012). Systemy dystantsiinoho navchannia - ohliad prohramnykh platform [Distance learning systems a review of software platforms]. Problemy vyshchoi shkoly. Innovatsii v osviti ta vyrobnytstvi. Kompiuterni tekhnolohii vosviti ta vyrobnytstviProblems of Education. Innovation in Education and Production. Computer Technologies in Education and Production, 1, 43-44 [in Ukrainian].

6. Mashaiko, I.V., Peleshenko, H.B., Pismenetska, I.Yu., \& Mashikeko, A.M. (2015). Perspektyvy vprovadzhennia suchasnykh informatsiynykh tekhnolohii v uchbovii protses vyshchykh medychnyh navchalnykh zakladiv [Prospects for the introduction of modern information technologies into the educational process of higher medical educational institutions]. Proceedings of the VIII Scientific and Practical Conference "Formuvannia suchasnoi kontseptsi vykladannia pryrodnychyh dystsyplin u medychnykh osvitnikh zakladah""Formation of the modern concept of teaching natural sciences in medical institutions. Kharkiv, p. 14 [in Ukrainian]. 